\title{
Upholding the Rule of Law through Judicial Dialogue
}

\author{
Koen Lenaerts*
}

The rule of law fundamentally means that, in a given legal order, any dispute is settled in accordance with — and only in accordance with — the applicable legal norms. It is therefore a condition sine qua non for proper justice. It is also among the foundational values of the Union listed in Article 2 of the Treaty on European Union (TEU), which means that - to paraphrase the 1986 judgment in Les Verts $^{1}$ - neither the EU institutions nor the Member States are above EU law. ${ }^{2}$

I would like first to illustrate the close ties that can be inferred from the recent case law of the Court of Justice of the European Union (the Court) between that value, the effective protection of the rights that $\mathrm{EU}$ law confers on individuals, and mutual trust between the Member States (Section I). In Section II, I will then explain how that mutual trust relates to the autonomy of the Union's legal order and justifies precluding the Member States from concluding international agreements removing any area of EU law from the scope of the preliminary reference procedure. In the third part, I will turn to the rule of law as applied to the EU itself, and will highlight—by reference to recent examples—-the Court's contribution to upholding it in the EU's external relations (Section III).

\section{Mutual trust in upholding the rule of law and protecting rights conferred by EU law}

\section{A. Protecting the preliminary ruling procedure}

Member States' courts are not only courts of national law but are also courts of EU law. By applying EU law in disputes submitted to them, they play a key role

\footnotetext{
* Koen Lenaerts, President of the Court of Justice of the European Union and Professor of European Union Law, Leuven University. All opinions expressed herein are personal to the author. Email: koen.lenaerts@law.kuleuven.be. This paper served as a basis for the keynote speech which the author delivered on 21 March 2019 at the Dickson Poon School of Law of the King's College, London, on 'EU Law, Trade Agreements and Dispute Resolution'.

${ }^{1}$ Judgment of 23 April 1986, Les Verts v Parliament (294/83, EU:C:1986:166), para. 23.

${ }^{2}$ See the speech that the author delivered on the occasion of the reception of a Doctorate Honoris Causa at the European University of Tirana on 13 December 2018, "The Court of Justice of the European Union and the rule of law', 3.
} 
in guaranteeing effective protection of the rights that EU law confers. In this way, they also contribute to upholding the rule of law within the EU. Since EU law must apply in a uniform manner throughout the Union, however, it is ultimately for the Court to ensure that in the interpretation of the Treaties the law is observed'. ${ }^{3}$ The dialogue which the preliminary ruling procedure establishes is key to that uniformity. ${ }^{4}$ Whenever a national court has doubts as to how it should interpret an EU act, it is entitled—or even required—to seek guidance from the Court of Justice; the answer has authority not only in the main proceedings but also in all cases where that same act applies. This has led the Court to explain, in Opinion 2/13 on accession to the European Convention on Human Rights (ECHR), that the preliminary reference procedure serves to ensure not only the consistency and full effect of EU law, but also 'its autonomy as well as, ultimately, the particular nature of the law established by the Treaties'. ${ }^{5}$

That imperative of uniformity also justifies the rule that, where a national court has doubts concerning the validity of an act of EU secondary law, that court should not itself review the legality of the act but should rather refer the matter to the Court of Justice. ${ }^{6}$ In most cases, the purpose of such a review of legality is to ensure compliance with rights conferred by EU rules of higher rank, for instance the Charter of Fundamental Rights of the European Union (the Charter). ${ }^{7}$

The preliminary ruling mechanism is therefore essential for ensuring protection of the rights that EU law confers on individuals, and indeed for upholding the rule of law within the EU.

That relationship was central to the Court's reasoning in Juizes Portugueses, a judgment delivered on 27 February 2018. ${ }^{8}$ The main question in this case was the following: can a national court or tribunal rely directly on EU law to protect its independence, when the latter is_-or might be - threatened by the government?

The dispute concerned alleged interference into the independence of members of the Portuguese Court of Auditors (Tribunal de Contas) as a result of temporary salary reduction measures. The measures formed part of cuts in

\footnotetext{
${ }^{3}$ Article 19(1), first subparagraph, TEU.

${ }^{4}$ Opinion 2/13 (Accession of the European Union to the ECHR) of 18 December 2014 (EU:C:2014:2454), para. 176.

${ }^{5}$ Ibid.

${ }^{6}$ Judgments of 22 October 1987, Foto-Frost (314/85, EU:C:1987:452) and of 6 December 2005, Gaston Schul Douane-expediteur (C-461/03, EU:C:2005:742), para. 17.

7 For a famous example when the Court declared invalid Directive 2006/24/EC of the European Parliament and of the Council of 15 March 2006 on the retention of data generated or processed in connection with the provision of publicly available electronic communications services or of public communications networks and amending Directive 2002/58/EC (O.J. 2006, L 105, p. 54), see the judgment of 8 April 2014, Digital Rights Ireland and Others (C-293/12 and C 594/12, EU:C:2014:238).

8 Judgment of 27 February 2018, Associação Sindical dos Juizes Portugueses (C-64/16, EU:C:2018:117).
} 
public spending decided in 2014 in response to the EU programme of financial assistance. The salary reductions related to public officers and employees, including members of the legislature, the executive, and the judiciary. Unlike the courts of auditors in some other Member States, the Tribunal de Contas may, in certain cases, operate as a court of law. The Union of Portuguese Judges challenged before Portuguese courts the salary reduction which, it argued, threatened the judicial independence guaranteed by Article 19 TEU and Article 47 of the Charter.

In the first part of the judgment, the Court clarified the requirement in Article 19(1), second subparagraph, TEU, that the Member States should ensure 'effective legal protection'. That provision applies ratione materiae to the 'fields covered by EU law', irrespective of whether the Member States are implementing EU law within the meaning of Article 51(1) of the Charter. ${ }^{9}$ The scope of application of the second subparagraph of Article 19(1) TEU is therefore broader than that of Article 47 of the Charter: it is not limited to national measures implementing EU law but applies horizontally to all proceedings before national courts in which EU law might apply.

The Court went on to explain the unbreakable link that exists between the right to effective legal protection in Article $19 \mathrm{TEU}$, the fundamental right to an effective remedy and the rule of law. Article 19 TEU 'gives concrete expression to the value of the rule of law stated in Article 2 TEU' and entrusts national courts and tribunals, in cooperation with the Court of Justice, with the responsibility for ensuring judicial review in the EU legal order. ${ }^{10}$ Since the very existence of judicial review to ensure compliance with EU law 'is of the essence of the rule of law', ${ }^{11}$ all 'courts or tribunals' in the Member States within the meaning of Article 267 of the Treaty on the Functioning of the European Union (TFEU) must meet the requirements of effective judicial protection. ${ }^{12}$ Thus, Article 19 TEU itself requires those national courts or tribunals, in so far as they may rule on questions concerning the application or interpretation of EU law, to be 'independent' within the meaning of Article 47, second subparagraph, of the Charter. ${ }^{13}$ That guarantee is 'inherent in the task of adjudication' and means, in particular, that judges should receive a level of remuneration 'commensurate with the importance of the functions they carry out'. ${ }^{14}$

Pivotal in the Court's reasoning is the link between judicial independenceand by extension the rule of law principle — and the procedure for a preliminary ruling. The former 'is, in particular, essential to the proper functioning of the

\footnotetext{
9 Ibid., para. 29.

${ }^{10}$ Ibid., para. 32.

${ }^{11}$ Ibid., para. 36, citing the judgment of 28 March 2017, Rosneft (C-72/15, EU:C:2017:236), para.

73. See on that latter judgment Section III below.

12 Ibid., para. 37.

13 Ibid., para. 42.

${ }^{14}$ Ibid., para. 46.
} 
[latter]' as it is settled case law that only national bodies that satisfy the criterion of independence may refer questions to the Court of Justice for a preliminary ruling. ${ }^{15}$ The underlying logic is simple: upstream, no hindrance should result from pressure exercised on the judge to refer-or not to refer-a request for a preliminary ruling to the Court of Justice or to ask a specific question instead of another one; downstream, only independent courts can ensure that preliminary rulings are duly respected. By protecting national judges' independence through Article 19 TEU, the Court thus also protects national judges as the arm of EU law (or, put more simply, as 'European judges'); ${ }^{16}$ by extension, it preserves the uniformity and effectiveness of EU law which the preliminary ruling procedure seeks to achieve.

As to the salary reductions at issue, they did not entail any breach of judicial independence: they were justified by mandatory requirements linked to the elimination of the Portuguese State's excessive budget deficit, were limited to a percentage of the salary varying in accordance with the level of salary, were temporary in nature and, most importantly, did not target the judiciary specifically but were part of a comprehensive effort to be made by public officials generally to cut spending in the public sector. ${ }^{17}$

\section{B. EU protection of the national judicial function as a basis for mutual trust}

That interpretation of Article 19 TEU has a broader consequence: it enhances mutual trust between the Member States as regards the rule of law. Mutual trust is based on the premiss that Member States share a set of common values on which the European Union is founded, as stated in Article 2 TEU. ${ }^{18}$ Compliance with those values is indeed a prerequisite for the accession of a new Member State to the EU. ${ }^{19}$ For some time, it may have been assumed that the monitoring of those values would essentially be political in nature. Juizes Portugueses makes it clear that there is also scope for judicial monitoring at Union level. The fundamental right to an effective remedy before an independent tribunal forms part of the requirement for 'effective legal protection' in Article 19 TEU, which is itself an essential component of the rule of law. As that provision applies 'horizontally' in areas covered by EU law, the Court has

\footnotetext{
15 Ibid., para. 43.

16 See the speech delivered by the author at the Supreme Administrative Court of the Republic of Poland on 19 March 2018, 'The Court of Justice and national courts: a dialogue based on mutual trust and judicial independence'.

17 Judgment of 27 February 2018, Associação Sindical dos Juízes Portugueses (C-64/16, EU:C:2018:117), paras 46-50.

18 Opinion 2/13 (Accession of the European Union to the ECHR) of 18 December 2014 (EU:C:2014:2454), para. 168, and judgment of 27 February 2018, Associação Sindical dos Juizes Portugueses (C-64/16, EU:C:2018:117), para. 30.

${ }^{19}$ Art. 49, first subparagraph, TEU.
} 
jurisdiction to monitor compliance with the rule of law in each Member State. ${ }^{20}$

The judgment in $L M$, delivered on 25 July 2018, further illustrates that mutual trust and the rule of law are closely related. ${ }^{21}$ That judgment confirms, although from a very different angle, that the premiss of Member States' compliance with the values in Article $2 \mathrm{TEU}$ is not absolute and hence that mutual trust is not blind trust. ${ }^{22}$

In $L M$, the High Court of Ireland asked, in essence, whether the judicial authority of a Member State may refuse to execute a European Arrest Warrant (EAW) delivered by the judicial authority of another Member State in accordance with Framework Decision 2002/584/JHA ${ }^{23}$ if there is a risk that the person concerned would suffer a breach of his or her fundamental right to an independent tribunal in case of surrender to that latter Member State. The principle of mutual recognition of judicial decisions (in this case of EAWs) is the 'cornerstone' of judicial cooperation in the area of freedom, security, and justice. It is itself based on mutual trust, which requires Member States to consider that all the other Member States comply with EU law and, in particular, with fundamental rights. In Aranyosi and Căldăraru, ${ }^{24}$ a case concerning the conditions of detention in the issuing Member State, the Court had already accepted limitations on mutual recognition and mutual trust in exceptional circumstances'. Subject to certain conditions, surrender of the requested person can be refused where it would otherwise result in that person being subjected to inhuman or degrading treatment within the meaning of Article 4 of the Charter. The question in $L M$ was therefore: should that apply by analogy to the risk of breach of the fundamental right to an independent tribunal, as guaranteed by Article 19 TEU and Article 47 of the Charter?

The Court's answer was 'Yes'. Subject to strict conditions, such a risk allows the executing judicial authority to refuse the surrender. ${ }^{25}$ The Court largely relied upon Juizes Portugueses to confirm that independence of the judiciary, which forms part of the 'essence' of the fundamental right to a fair trial, ${ }^{26}$ is key

${ }^{20}$ It is against that background that the Commission initiated last year infringement proceedings against the Republic of Poland for an alleged impairment caused to the independence of the Polish Supreme Court with a new retirement regime applicable to its members (pending Case C-619/18, Commission v Poland).

${ }^{21}$ Judgment of 25 July 2018, Minister for Justice and Equality (Deficiencies in the system of justice), (C216/18 PPU, EU:C:2018:586).

${ }^{22}$ See the speech given by the author in Tirana on 13 December 2018 (p. 8), cited at fn 1. See also Lenaerts, 'La vie après l'avis: exploring the principle of mutual (yet not blind) trust', 2017 Common Market Law Review, 820-2.

${ }^{23}$ Framework Decision 2002/584/JHA of 13 June 2002 on the European arrest warrant and the surrender procedures between Member States (O.J. 2002 L 190, p. 1).

24 Judgment of 5 April 2016, Aranyosi and Căldăraru (C-404/15 and C-659/15 PPU, EU:C:2016:198).

25 Judgment of 25 July 2018, Minister for Justice and Equality (Deficiencies in the system of justice) (C216/18 PPU, EU:C:2018:586), para. 59.

${ }^{26}$ Ibid., para. 48. 
to effective judicial protection and, in turn, to upholding the rule of law within the EU. ${ }^{27}$ That independence is also pivotal in the EAW mechanism: Framework Decision 2002/584 establishes a simplified system of direct surrender between the 'judicial authorities' of the Member States, based on the premiss on the premiss that they all meet the requirements of effective judicial protection. ${ }^{28}$

As such a limitation derogates from the premiss of mutual trust between the Member States, refusing the execution of an EAW on that basis is nevertheless possible in exceptional circumstances only. As a first step, the executing judicial authority should carry out an objective assessment of the operation of justice in the issuing Member State. That involves verifying whether there is a real risk of systemic and generalized deficiencies in that Member State and hence of breaches of the fundamental right to a fair trial. The Court pointed out that information to that effect contained in the reasoned proposal submitted by the Commission to the Council on the basis of Article 7(1) TEU is 'particularly relevant'. ${ }^{29}$ If the executing judicial authority finds that there is such a real risk, it must, in a second step, assess specifically and precisely whether, in the particular circumstances of the case, there are substantial grounds for believing that, following surrender, the requested person will run that risk. ${ }^{30}$ The executing judicial authority must request from the issuing judicial authority any supplementary information necessary for assessing whether there is such a risk. ${ }^{31}$ It is only if the European Council adopts a decision based on Article 7(2) TEU, determining that there is a serious and persistent breach of the principles set out in Article 2 TEU in the issuing Member State, and the Council then suspends Framework Decision 2002/584 in respect of that Member State, that the executing judicial authority is required to refuse automatically to execute any EAW which that Member State issues, without having to carry out any assessment of whether the person concerned runs the risk that the essence of his right to a fair trial will be affected. ${ }^{32}$ Following the judgment in $L M$, the referring court carried out such an assessment and held that the conditions for refusing execution of the EAW were not met. ${ }^{33}$

\section{The integrity of judicial dialogue and the autonomy of the Union's legal order}

So far, I have stressed the importance of judicial independence and of the preliminary reference mechanism to ensure that EU law is observed and, in

27 Ibid., paras 51-53.

28 Ibid., paras 55 and 58.

${ }^{29}$ Ibid., para. 61.

30 Ibid., para. 68.

31 Ibid., para. 76.

32 Ibid., para. 82.

33 High Court (Ireland), 19 November 2018, [2018] IEHC 639. 
turn, to uphold the rule of law within the EU. That is not, however, the only functional protection which EU law offers to national courts and tribunals. As stated at the beginning of this article, where national courts apply EU law, they must have the possibility and, in some cases, have the obligation to engage in a dialogue with the Court of Justice. That is essential not only to the uniformity and effectiveness of EU law, but also-by extension - to the autonomy of EU law. Those objectives would be seriously compromised if either the EU political institutions or the Member States could remove a given field of EU law from the jurisdiction of national courts and thereby from the scope of the preliminary reference procedure.

A threat to the autonomy of the Union's legal order resulted, for instance, from the draft agreement creating a unified patent litigation system, which the Court examined in Opinion 1/09. ${ }^{34}$ That draft agreement conferred on an international court, placed outside the institutional and judicial framework of the EU, exclusive jurisdiction to hear a significant number of actions brought by individuals concerning the envisaged Community patent and to interpret and apply EU law relevant to that new intellectual property right. The Court of Justice held that that draft agreement, by removing the entire body of litigation from the EU system of judicial protection, would have undermined the direct cooperation between the Court and national courts which Article 267 TFEU puts in place and therefore threatened 'the very nature of the law established by the Treaties'. ${ }^{35}$

A more recent illustration is the judgment in $A$ chmea, ${ }^{36}$ delivered only a week after Juizes Portugueses. It is worth spending a bit more time on this case as that judgment's rationale and significance has sometimes been misunderstood. Slovakia challenged before the German courts an award by an arbitral tribunal established in accordance with the 1991 Bilateral Investment Treaty (BIT) between the then Czech and Slovak Federative Republic and the Netherlands. Slovakia had decided to liberalize its private sickness insurance sector in 2004. That prompted Achmea, an undertaking belonging to a Dutch insurance group, to invest in Slovakia. Later on, however, Slovakia went back on that liberalization, in particular by prohibiting the distribution of profits generated by private sickness insurance activities. Achmea sought compensation of the harm that that U-turn had caused to it before the arbitral tribunal. The tribunal ordered the Slovak Republic to pay Achmea damages in the principal amount of EUR 22.1 million.

The Slovak Republic contested the decision before the German courts (the parties had chosen Germany as the place of arbitration). As Slovakia had become an EU Member State, doubts arose as to the compatibility of the arbitration

34 Opinion 1/09 (Agreement creating a Unified Patent Litigation System) of 8 March 2011 (EU:C:2011:123).

35 Ibid., paras 84 and 85.

36 Judgment of 6 March 2018, Achmea, C-284/16 (EU:C:2018:158). 
clause in the BIT with, in particular, the preliminary ruling mechanism and the prohibition for the Member States, in Article 344 TFEU, to 'submit a dispute concerning the interpretation or application of the Treaties to any method of settlement other than those provided for therein'. The Bundesgerichtshof (Federal Court of Justice, Germany) therefore referred the case to the Court of Justice.

In its preliminary considerations, the Court reminded of its finding in Opinion 2/13 that the autonomy of EU law with respect both to the law of the Member States and to international law is justified by the essential characteristics of the EU and its legal order, relating in particular to the constitutional structure of the EU and the very nature of EU law. ${ }^{37}$ It is in order to preserve those characteristics that the Treaties have established a judicial system intended to ensure consistency and uniformity in the interpretation of EU law, ${ }^{38}$ in which national courts and tribunals share responsibility with the Court of Justice for ensuring the full application of EU law and judicial protection of the rights created by that law. ${ }^{39}$ The Court held that the preliminary ruling mechanism is the 'keystone' of that judicial system and an essential instrument for preserving the particular nature of EU law. ${ }^{40}$ That formed the background to a three-step reasoning.

In the first step, the Court observed that the disputes the arbitral tribunal was called to adjudicate were liable to relate to the interpretation or application of EU law, in particular to rules on the freedom of establishment and the free movement of capital. Although the arbitral tribunal's jurisdiction was formally limited to alleged infringements of the BIT, it was required under Article 8(6) of that agreement to take into account 'the law in force in the Contracting Party concerned' and 'other relevant agreements between the Contracting Parties'. That necessarily covers EU law. ${ }^{41}$

In the second step, the Court noted that the arbitral tribunal did not form part of the EU judicial system and could not be regarded as a court or tribunal within the meaning of Article 267 TFEU. ${ }^{42}$ That second finding was particularly important because in Opinion 1/09 the Court decided that decisions of a tribunal situated within the EU judicial system, including a tribunal 'common' to several Member States such as the Benelux Court of Justice, ${ }^{43}$ are subject to

${ }^{37}$ Ibid., para. 33.

${ }^{38}$ Ibid., para. 35.

39 Ibid., para. 36.

${ }^{40}$ Ibid., para. 37.

${ }^{41}$ Ibid., paras 41 and 42.

42 Ibid., para. 49.

43 The Court confirmed in its judgment of 4 November 1997, Parfums Christian Dior (C-337/95, EU:C:1997:517, para. 21), and later in its judgment of 14 June 2011, Miles and Others (C-196/09, EU:C:2011:388, para. 40) that the Benelux court may refer questions for a preliminary ruling to the Court of Justice as (i) it is entrusted with the task of ensuring that the legal rules common to the Benelux States are applied uniformly and (ii) the procedure before it is a step in the proceedings before the national courts leading to definitive interpretations of the common rules. 
mechanisms capable of ensuring the full effectiveness of EU rules. ${ }^{44}$ In contrast, the arbitral tribunal established under the BIT was situated outside the judicial systems of the Contracting Parties and thus outside the EU judicial system. The very raison d'etre of the arbitration clause was precisely to avoid Dutch or Slovak courts' jurisdiction. The clause epitomized, in that sense, mutual 'distrust' between the Contracting Parties, two Member States.

In the third step, the Court examined whether review of the arbitral award before the courts of a Member State was nevertheless possible and whether that review would allow the preliminary reference mechanism to fulfil its essential functions as regards the effectiveness and autonomy of EU law. In this particular case, review of the arbitral award was possible under German law. However, such judicial review can be exercised only to the extent that national law permits and German law provides only for limited judicial review of such arbitral awards, concerning in particular the validity of the arbitration agreement and whether recognizing and enforcing the arbitral award would be consistent with public policy. ${ }^{45}$ It is true that in Eco Swiss, ${ }^{46}$ the Court had admitted that the requirements of efficient commercial arbitration proceedings may justify a limitation on the review of arbitral awards by the courts of the Member States, 'provided that the fundamental provisions of EU law can be examined in the course of that review and, if necessary, be the subject of a reference to the Court for a preliminary ruling. ${ }^{47}$ However, the Court declined to apply that reasoning by analogy. The arbitral proceedings in Achmea 'derive[d] from a treaty by which Member States agree[d] to remove from the jurisdiction of their own courts, and hence from the $[\mathrm{EU}]$ system of judicial remedies ... disputes which may concern the application or interpretation of EU law'. ${ }^{48}$

On the basis of its three-step reasoning, the Court concluded that the arbitration clause in the BIT had an adverse effect on the autonomy of EU law and therefore violated that law. ${ }^{49}$ In the last part of the judgment, the Court distinguished this case from settled case law under which an international agreement concluded by the EU and establishing a dispute-settlement mechanism is in principle compatible with EU law, provided that the autonomy of the EU and its legal order is respected..$^{50}$ That case law did not apply in Achmea because the arbitration clause in the BIT, which is an agreement binding upon Member States, was such as to call into question both mutual trust between them and the particular nature of EU law, and therefore amounted to a violation of the

44 Opinion 1/09 (Agreement creating a Unified Patent Litigation System) of 8 March 2011 (EU:C:2011:123, para. 82), cited at para. 43 of the judgment of 6 March 2018, Achmea, C284/ 16 (EU:C:2018:158).

45 Judgment of 6 March 2018, Achmea (C-284/16, EU:C:2018:158), para. 53.

46 Judgment of 1 June 1999, Eco Swiss (C-126/97, EU:C:1999:269), paras 35, 36, and 40.

47 Judgment of 6 March 2018, Achmea (C-284/16, EU:C:2018:158), para. 54.

48 Ibid., para. 55.

49 Ibid., para. 59.

50 Ibid., para. 57 and case law cited. 
principle of sincere cooperation set out in the first subparagraph of Article 4(3) TEU. ${ }^{51}$ Following the Court's preliminary ruling, the Bundesgerichtshof annulled the arbitral award. ${ }^{52}$

What the Court refused to accept in Achmea was an anachronism: following accession of Slovakia to the EU on 1 May 2004, distrust can no longer be the premiss characterizing the relations between Member States. On the contrary, the premiss within the Union must be mutual trust in respect of the values set out in Article 2 TEU. Since those values include, in particular, the rule of law and justice, any Member State should in principle be confident that, in the fields covered by Union law, the judicial system of the other Member States ensures effective legal protection within the meaning of Article 19 TEU. It is here that a clear link appears with the reasoning in Juizes Portugueses: the mutual trust requirement is all the more justified given that the Court of Justice bears judicial responsibility for monitoring effective compliance by the Member States with the rule of law, through the application of Article 19 TEU read together with Article 2 TEU.

It is against that constitutional background that Achmea should be understood, and certainly not as a rejection of international arbitration en bloc as has - erroneously - been suggested. In particular, it follows from the distinction drawn in the Achmea judgment between arbitration based on a BIT concluded between Member States and commercial arbitration that a dispute such as the one between Achmea and Slovakia could have been lawfully submitted to an arbitral tribunal based on an arbitration agreement between those parties: such an agreement would have involved no expression of 'distrust' on the part of a Member State vis-à-vis the judicial system of another Member State; and nothing would have stood in the way of preserving the essential characteristics of EU law through judicial review of the arbitral award under the conditions set out in Eco Swiss.

\section{Enhancing the rule of law in the Union's external action}

The purpose of this last part is to stress that the Court's attachment to the rule of law and the essential function of judicial dialogue with national courts to uphold it is not confined to litigation targeting action by the Member States. That value is equally important when it comes to monitoring action by the EU institutions, which is in line with the scope of Article 2 TEU.

Let me illustrate that point by reference to two relatively recent cases concerning the union's external relations.

\footnotetext{
51 Ibid., para. 58.

52 Beschluss vom 31. Oktober 2018 (I ZB 2/15).
} 
The first case is the Court's judgment in Rosneft. ${ }^{33}$ This case concerned restrictive measures adopted in the framework of the Common Foreign and Security Policy (CFSP) against a Russian company active in the oil and gas sectors. Those sanctions were a response to the actions of the Russian Federation allegedly destabilizing Ukraine. In its action for judicial review before the High Court of Justice (England \& Wales), Rosneft argued that both the EU acts that formed the basis of the restrictive measures, that is to say a CFSP Decision ${ }^{54}$ and a Council Regulation, ${ }^{55}$ and the national measures implementing them were invalid. The grounds of invalidity included an infringement of the EU-Russia Partnership Agreement, a failure to state reasons, a breach of the equal treatment principle and a misuse of powers on the part of the Council insofar as the contested acts targeted the oil sector, as well as a lack of proportionality. ${ }^{56}$ Since the High Court entertained doubts in this respect, it referred to the Court, inter alia, a question on the validity of the CFSP Decision and the Council Regulation. The High Court observed, however, that it follows from the second subparagraph of Article 24(1) TEU and Article 275 TFEU that the Court in principle lacks jurisdiction over CFSP acts. Therefore, it invited the Court, in the first place, to ascertain whether it could decide on the validity of the CFSP Decision in the context of a preliminary ruling. That jurisdictional issue was particularly important with regard to the rule of law because, as the High Court pointed out and as the Rosneft judgment expressly confirms, ${ }^{57}$ that court lacked jurisdiction to review the validity of EU acts itself, including the CFSP Decision. ${ }^{58}$

The main difficulty stemmed from the wording of the second subparagraph of Article 275 TFEU, which introduces two exceptions to the Court's lack of jurisdiction as regards CFSP acts. First, the Court has jurisdiction to monitor compliance with the reciprocal non-affectation rule contained in Article 40 TEU. Secondly, the Court has jurisdiction to 'rule on proceedings, brought in accordance with the conditions laid down in the fourth paragraph of Article 263 [TFEU], reviewing the legality of decisions providing for restrictive measures against natural or legal persons adopted by the Council on the basis of [the provisions in the EU Treaty relating to the CFSP]'.59 The Court had no difficulty in confirming its jurisdiction to monitor compliance with Article

\footnotetext{
53 Judgment of 28 March 2017, Rosneft (C-72/15, EU:C:2017:236).

54 Council Decision 2014/512/CFSP of 31 July 2014, concerning restrictive measures in view of Russia's actions destabilizing the situation in Ukraine (OJ 2014, L 229, p. 13).

55 Council Regulation (UE) No 833/2014 of 31 July 2014 concerning restrictive measures in view of Russia's actions destabilizing the situation in Ukraine (OJ 2014, L 229, p. 1, and corrigendum, OJ 2014, L 246, p. 59).

56 Judgment of 28 March 2017, Rosneft (C-72/15, EU:C:2017:236), para. 35.

57 Ibid., paras 77-80.

58 See the case law cited at fn 4 .

59 Emphasis added.
} 
40 TEU pursuant to a request for a preliminary ruling. That is because Article 275 TFEU does not specify any particular means by which such judicial review is to be carried out. ${ }^{60}$ However, does the express reference to annulment proceedings in Article 275 TFEU preclude the Court from exercising judicial review of restrictive measures in the context of a reference for a preliminary ruling?

In its answer to that delicate question, the Court recalled that the right for persons bringing an action before national courts to challenge the legality of an $\mathrm{EU}$ act on which the contested national decision or measure is based, in order for the national court to refer that question of validity to the Court, is inherent in the complete EU system of legal remedies and procedures. ${ }^{61}$ The only exception to that right is where the person concerned unquestionably had the right to seek annulment of such an act before the General Court and has failed to do so. That exception, nevertheless, was not relevant in this context as Rosneft had brought parallel proceedings before the General Court. More importantly, the Court referred to the rule of law, on which not only the Union as a supranational organization is based, but also the Union's action on the international scene, pursuant to Article 21(1) TEU. ${ }^{62}$ Both the rule of law and the right to effective judicial protection guaranteed by Article 47 of the Charter, coupled with the importance of the preliminary reference procedure for upholding the rule of law within the EU, imply that the exclusion of the Court's jurisdiction under the CFSP must be interpreted strictly. ${ }^{63}$ The Court thus confirmed its jurisdiction to deliver a preliminary ruling on the validity of a CFSP decision that relates to restrictive measures against natural or legal persons. As to the reference made to annulment proceedings in the second subparagraph of Article 275 TFEU, the Court sidestepped that obstacle by emphasizing that the reference to the latter provision contained in Article 24(1) TEU concerns the type of CFSP decisions that may be reviewed by the Court and not the type of procedure through which such review can be exercised. ${ }^{64}$ On substance, the Court identified no element such as to call into question the validity of the CFSP Decision and the Council Regulation at issue.

The Rosneft judgment provides yet another piece of evidence concerning the value of the preliminary reference mechanism for the rule of law. It does so, however, from a very different perspective than in Juizes Portugueses or Achmea, that is by stressing that preliminary references questioning the validity of EU acts are an essential complement to direct actions for reviewing the legality of such acts. Also, the right to obtain compensation for damage caused by the

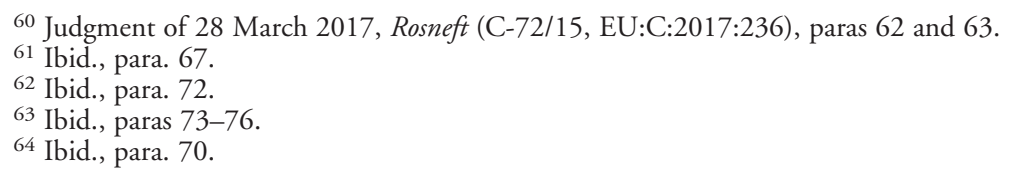

${ }^{60}$ Judgment of 28 March 2017, Rosneft (C-72/15, EU:C:2017:236), paras 62 and 63.

${ }^{61}$ Ibid., para. 67.

62 Ibid., para. 72

${ }^{64}$ Ibid., para. 70. 
Council acting in the field of the CFSP contributes to upholding the rule of law in that area of EU competence. ${ }^{65}$

The second illustration is the judgment delivered on 27 February 2018 in Western Sahara Campaign. ${ }^{66}$ The main proceedings were, once again, pending before the High Court of Justice (England \& Wales). Western Sahara Campaign, a voluntary organization supporting the right of the people of Western Sahara to self-determination, which opposed inter alia ${ }^{67}$ the inclusion of the waters adjacent to Western Sahara within the scope of national measures implementing the Fisheries Partnership Agreement between the EU and Morocco $^{68}$ and its 2013 Protocol setting out the fishing opportunities and financial contribution provided for in that agreement. ${ }^{69}$ Western Sahara Campaign argued that those EU acts were manifestly incompatible with international law-in particular the right to self-determination-insofar as they include the territory of Western Sahara and the waters adjacent thereto, and pointed to the fact that there was no evidence that the people of Western Sahara were to derive any benefit from them. The High Court asked the Court of Justice whether the Fisheries Partnership Agreement and its 2013 Protocol were valid.

The Court's reasoning demonstrates, both in respect of the admissibility of the reference for a preliminary ruling and in respect of the substantive examination of those EU acts, that the political organs of the Union-in particular the Council—are not 'above the law' when concluding international agreements that are binding upon the Union and, by extension, upon its Member States. ${ }^{70}$

The Council argued that the reference was inadmissible as the Court should have no jurisdiction to examine the validity of international agreements such as the Fisheries and Partnership Agreement and its 2013 Protocol. The Court rejected that view. International agreements are, from the date of their entry into force, an integral part of the EU legal order and must therefore comply not only with the Treaties and all constitutional principles deriving therefrom, but also with rules of public international law that are binding upon the Union. ${ }^{71}$ Recalling the

65 See, to that effect, the judgment of 30 May 2017, Safa Nicu Sepahan v Council (C-45/15 P, EU:C:2017:402), para. 35; see also the Opinion of Advocate General Pitruzzella in HTTS v Council (C-123/18 P, EU:C:2019:173), para. 18.

${ }^{66}$ Judgment of 27 February 2018, Western Sahara Campaign UK, C266/16, EU:C:2018:118.

67 Originally, Western Sahara Campaign also opposed certain measures implementing the EuroMediterranean Agreement establishing an association between the European Union and their Member States, of the one part, and the Kingdom of Morocco, of the other part (OJ L 70, p. 2). Following a judgment of 21 December 2016, Council v Front Polisario (C-104/16 P, EU:C:2016:973), the High Court of Justice withdrew its questions concerning the validity and interpretation of that Association Agreement.

${ }^{68}$ OJ 2006, L 141, p. 4.

69 OJ 2013, L 328, p. 2.

70 Article 216(2) TFEU.

${ }^{71}$ Judgment of 27 February 2018, Western Sahara Campaign UK(C-266/16, EU:C:2018:118), paras 46 and 47. 
complementary nature of annulment proceedings and preliminary reference proceedings for reviewing the legality of EU acts, the Court confirmed that it had jurisdiction to answer the preliminary reference concerning the validity of the agreement and protocol at issue. ${ }^{72}$ The Court nevertheless took into account the fact that the agreement and the protocol are also binding on non-Member States and thus held that the review of legality concerns the Council decisions whereby the EU had approved them, in the light of their actual content. ${ }^{73}$

On substance, the difficulty of the case resulted from the fact that no reference was made to Western Sahara in the agreement and protocol at issue. The Court stressed at the outset that the question of validity raised by the referring court was based on the premiss that those acts do apply to Western Sahara and the waters adjacent to it. That premiss was nevertheless not correct. The reasoning that led the Court to that conclusion illustrates a profound attachment to the international rule of law. In the first place, the Court interpreted the concept of 'territory of Morocco'. This concept is also used in the Association Agreement with Morocco, which forms part of the same 'body of agreements' as the Partnership and Fisheries Agreement, and in the 2013 Protocol. The concept should therefore have the same meaning under each of those agreements. Next, the Court recalled its decision in Front Polisario that including Western Sahara in the 'territory of Morocco' would be incompatible with certain rules of general public international law, namely the principle of self-determination, stated in Article 1 of the Charter of the United Nations, and the principle of the relative effect of treaties, expressed in Article 34 of the Vienna Convention on the Law of Treaties. ${ }^{74}$ By contrast, the concept of 'waters falling within the sovereignty or jurisdiction of the Kingdom of Morocco' was not used in the Association Agreement and the Court could not therefore rely here on its reasoning in Front Polisario. However, international law again played an essential role in the Court's interpretive reasoning. It follows from the Montego Bay Convention on the Law of the Sea (1986), in essence, that a coastal State can exercise 'sovereignty or jurisdiction' only on waters adjacent to its own territory, which, as a result of the first part of the reasoning, necessarily excluded waters adjacent to Western Sahara. The Court reached a similar conclusion concerning the concept of a 'Moroccan fishing zone' used in the 2013 Protocol, in particular because the same expression, used in the Fisheries Partnership Agreement, referred to 'waters falling within the sovereignty or jurisdiction of ... Morocco' and, moreover, the coordinates specifying these zones were notified by Morocco after the protocol had entered into force and did not therefore form part of it. ${ }^{75}$

\footnotetext{
72 Ibid., para. 48.

73 Ibid., paras 50 and 51.

${ }^{74}$ Ibid., para. 63, citing paras 88-93, 100, 103-107, and 123 of the judgment of 21 December 2016, Council v Front Polisario (C-104/16 P, EU:C:2016:973).

75 Judgment of 27 February 2018, Western Sahara Campaign UK(C-266/16, EU:C:2018:118), paras 76-81.
} 
Thus interpreted, the Fisheries and Partnership Agreement and its 2013 Protocol raised no doubts as to their validity.

\section{Conclusion}

The cases discussed in this article demonstrate that the Court is ready to bear its full responsibility for upholding the rule of law within the EU. That responsibility lies at the very heart of its function of ensuring that in the interpretation and application of the Treaties the law is observed'. Those cases equally attest to the fact that the Court would not be in a position to uphold the rule of law and thus to preserve the Union's autonomous legal order without judicial dialogue with national courts. In addition to that systemic point, what we can observe is that the Court genuinely applies the rule of law as it is enshrined in Article 2 TEU: it is a foundational value of the Union enforceable not only in the context of Member States' actions but also in respect of the actions of the Union's institutions. As I hope I have demonstrated, judicial disputes touching on the rule of law are a perfect laboratory for studying the constitutional nature of EU integration and serve to shed light on some of the most debated legal challenges that it currently faces. 